\title{
GAS- SEQUENCING BATCH REACTOR SEBAGAI TEKNOLOGI PENGOLAHAN AIR LIMBAH RUMAH PEMOTONGAN AYAM
}

\author{
Bunga Oktafani \\ Jurusan Teknik Lingkungan, Fakultas Arsitektur Lanskap dan Teknologi Lingkungan, \\ Universitas Trisakti, Jakarta, Indonesia
}

Email korespondensi: bunga08214013@std.trisakti.ac.id

\begin{abstract}
ABSTRAK
Permintaan terhadap produk peternakan meningkat setiap tahun seiring dengan bertambahnya jumlah penduduk serta meningkatnya pengetahuan dan kesadaran masyarakat tentang pentingnya mengonsumsi pangan yang bergizi. Daging ayam merupakan sumber bahan pangan hewani, yang mengandung gizi yang cukup tinggi berupa protein dan energi. Selain itu, daging ayam cukup digemari masyarakat karena dipasarkan dengan harga yang relatif murah.Karya ilmiah ini mengkaji penggunaan Sequencing Batch Reactor (SBR) dengan menggunakan Granular Activated Sludge (GAS) dalam mengolah air limbah Rumah Pemotongan Ayam (RPA). Kajian dilakukan dengan penelusuran literatur. Hasil penelusuran literatur meunjukkan, teknologi pengolahan dengan menggunakan GAS secara umum banyak digunakan pada reaktor GAS. Air limbah Rumah Pemotongan Ayam (RPA) mengandung (Biological Oxygen Demand) BOD, (Chemical Oxygen Demand) COD, (Total Suspended Solid) TSS, minyak dan lemak yang tinggi dengan komposisi berupa zat organik. Menurut beberapa penelitian sebelumnya GAS-SBR memiliki kemampuan untuk mengolah air limbah dengan kandungan organik yang tinggi.
\end{abstract}

Kata Kunci: Sequencing Batch Reactor ; Granular Activated Sludge ;Air Limbah ; Rumah Pemotongan Ayam

\section{PENDAHULUAN}

Seiring dengan tingginya tingkat konsumsi daging ayam di masyarakat, maka mendorong adanya pertumbuhan usaha disektor hilir (pengolahan) yaitu usaha pemotongan ayam. Rumah Potong Ayam (RPA) merupakan usaha di bidang peternakan dalam pemotongan ayam hidup dan mengolah menjadi karkas yang siap konsumsi. Banyaknya industri RPA yang muncul menimbulkan masalah lingkungan, yaitu air limbah yang dihasilkan dibuang begitu saja tanpa diolah sehingga dapat menimbulkan pencemaran. Menyikapi permasalahan tersebut maka dibutuhan suatu sistem pengolahan yang efektif, fleksibel, dan memiliki efisiensi ruang agar kualitas air limbah RPA dapat memenuhi standar buangan. Salah satu sistem pengolahan yang dapat dilakukan adalah dengan kombinasi GAS-SBR. GAS-SBR mempunyai kelebihan dalam beberapa hal dibandingkan dengan pengolahan air limbah dengan lumpur aktif konvensional. Biomassa granular ini dapat terbentuk pada kondisi aerobik tanpa perlu material lain sebagai inti. Berbagai referensi menyebutkan keunggulan teknologi ini terutama pada kemampuan pengendapan biomassa yang cepat, karena densitasnya yang besar, sehingga memperkecil kebutuhan lahan untuk pengendapan. Karya ilmiah ini disusun untuk mengkaji kinerja kombinasi teknologi GAS-SBR dalam mengolah air limbah RPA

\section{TINJAUAN PUSTAKA}

\section{Air limbah RPA}

Air limbah sampai dengan saat ini sebagian besar masuk ke badan air penerima lewat drainase atau saluran air tanpa diolah terlebih dahulu (Iswanto, 2010). Air limbah RPA berasal dari air bekas pakai yang bercampur dengan darah (Singgih dan Kariana,2008). Air bekas yang dimaksud adalah air buangan dari sisa proses pencelupan ayam kedalam air panas dan proses pencucian. Pencelupan dilakukan untuk mempermudah pencabutan bulu, dan pencucian ayam dilakukan untuk membersihkan karkas dari sisa bulu dan jeroan. Air limbah RPA mengandung zat pencemar seperti BOD (Biological Oxygen Demand), COD (Chemical Oxygen Demand) dan Amonia yang tinggi (Kholif dan Ratnawati, 2017). Tingginya kandungan BOD pada air limbah, menandakan tingginya jumlah bahan organik, populasi organisme pengurai dan laju penguraian 
bahan organik yang memanfaatkan oksigen telarut. Sedangkan, tingginya kandungan COD, menandakan tingginya jumlah oksigen yang dibutuhkan untuk mengoksidasi seluruh bahan kimia baik organik maupun anorganik dalam air. Efek dari kegiatan rumah pemotongan terhadap kesehatan penduduk kota diungkapkan oleh Singh dan Neelam (2011) bahwa warga yang tinggal di sekitar rumah potong hewan mengalami penurunan kualitas kesehatan akibat dari pencemaran kualitas air dan udara. Kasus peningkatan batuk berlebih, demam tifoid, diare, malaria dan nyeri otot dilaporkan terjadi pada manusia. Demikian pula diare, trypnosomiasis, infestasi parasit internal dan eksternal, demam dan kasus penurunan hasil susu juga dilaporkan pada hewan.

\section{Sequencing batch reactor}

Berbagai pengembangan proses pengolahan air limbah telah dilakukan untuk mendapatkan hasil pengolahan yang optimum baik secara fisik, kimia maupun biologi (Adeline dkk, 2015). Salah satu sistem pengolahan yang dapat dilakukan adalah dengan GAS-SBR. Dasar pengoperasian SBR adalah pengisian dan pengosongan reaktor. Air limbah dialirkan ke dalam reaktor dalam waktu tertentu, lalu dilakukan pengolahan dalam reaktor dalam waktu yang direncanakan secara batch (Vigneswaran dkk, 2011). SBR dioperasi dalam 5 tahapan, yaitu Fill (tahap pengisian), React (tahap reaksi), Settle (tahap pengendapan), Draw (tahap pengosongan) dan Idle (tahap istirahat) (Duta dan Sarkar, 2015) Adapun ilustrasi proses SBR digambarkan sebagai berikut :

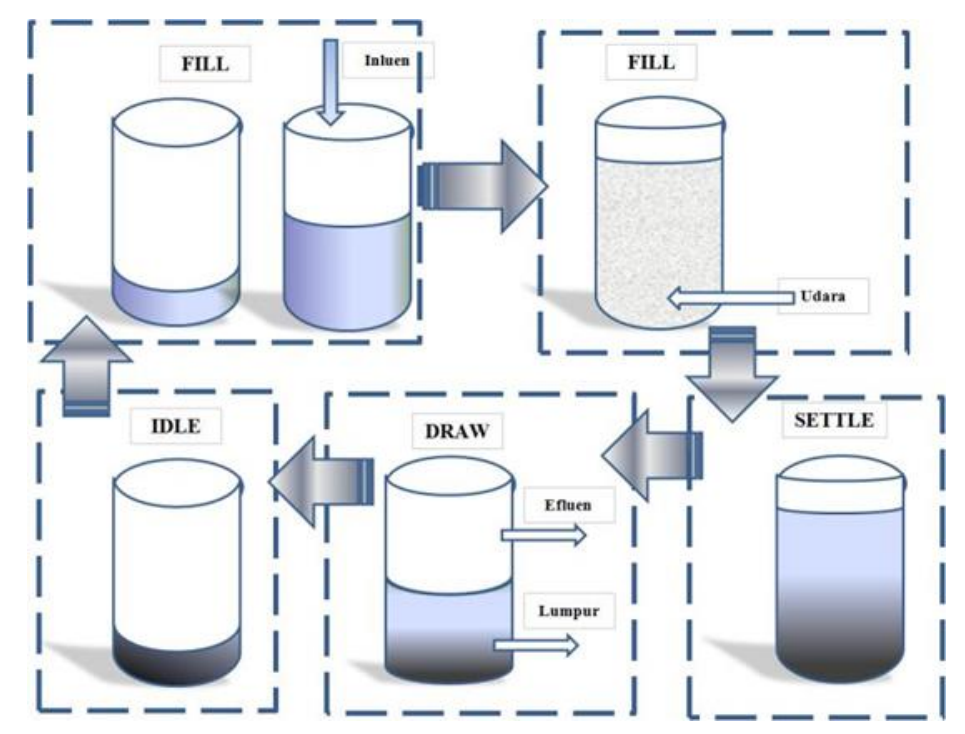

Gambar 1. Siklus dalam Sequencing Batch Reactor (SBR)

\section{Granular activated sludge}

GAS didefinisikan sebagai agregat yang berasal dari mikroorganisme yang tidak berkoagulasi apabila gaya geser hidrodinamik diturunkan dan secara signifikan mengendap lebih cepat. Apabila dibandingkan dengan flok lumpur aktif, GAS mempunyai diameter dan metode pemanenan tertentu (Ni, 2013). Castro-Barros, (2013) menyatakan GAS merupakan bentuk biofilm yang tumbuh tanpa adanya tambahan media luar. Pembentukan ini terjadi akibat adanya materi yang disebut EPS yang dikeluarkan oleh mikroorganisme. Materi ini merupakan susunan dari protein, polisakarida, asam humus, dan lemak yang meningkatkan adhesi sel (Adav dkk, 2008).

Meskipun memiliki kemiripan, GAS mempunyai struktur yang berbeda dengan flok lumpur aktif. Perbedaan ini terdapat selain pada kondisi fisik (Minh, 2006), juga pada proses pembentukan dan konsorsium bakteri pembentuknya (Winkler, 2012). Winkler (2012) mengungkapkan perbedaan struktur keduanya, yaitu pada GAS berbentuk kondisi yang lebih seragam antar lapisan, dimana secara konsentris dengan lapisan (dari luar ke dalam) kondisi yang terbentuk adalagh aerobik, anoksik, dan anerobik, hal ini tidak terbentuk pada flok lumpur aktif, meskipun mikroorganisme pembentunya relatif sama.

Pada awalnya teknologi granular ini secara hanya dikenal pada pengolahan air limbah secara anaerobik, khususnya reaktor UASB (Upflow Anaerobic Sludge Blanket). Morgenroth dkk, 
(1997) menyebutkan bahwa biomassa granular ini dapat terbentuk pada kondisi aerobik, tanpa perlu material lain sebagai inti. Berbagai referensi menyebutkan keunggulan teknologi ini terdapat pada kemampuan pengendapan biomassa yang cepat, karena densitasnya yang besar, sehingga memperkecil kebutuhan lahan untuk pengendapan. Teknologi ini dianggap sebagai alternatif yang baik untuk lumpur aktif. GAS juga memungkinkan untuk diterapkan pada skala komunal (Li dkk, 2006; Chiavola dkk, 2010), meskipun untuk limbah domestik memerlukan waktu start-up yang lebih panjang (de Kreuk dan Loosdrecht, 2006; Loosdrecht,2011). Kekurangan lain pada GAS adalah pembentukan granulasi yang memerlukan waktu lama, dan kemungkinan mikroba yang tergranulasi terutama terbentuk dari bakteri Patogen (Ivanov dan Tay, 2006).

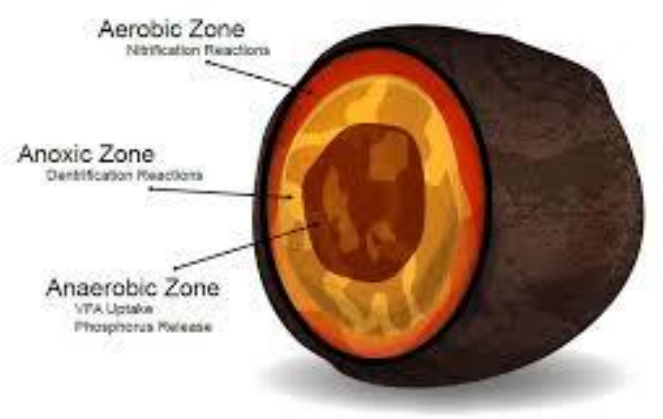

Gambar 2. Granular Activated Sludge

\section{PENUTUP}

Berdasarkan pembahasan mengenai air limbah RPA dan pengunaan tekonologi GAS-SBR, diperlukan eksplorasi lebih lanjut pada reaktor SBR dengan GAS bertujuan untuk mendapatkan pemahaman yang lebih baik terkait dengan keefektifan dan efisiensi pengolahan.

\section{DAFTAR PUSTAKA}

Adav S S, Lee, D. J, Show, K. Y, Tay, J. H 2008. Aerobic Granular Sludge: Recent Advances, Biotechnology Advances 26 (2008), 411-423.

DOI: https://doi.org/10.1016/j.biotechadv.2008.05.002.

Adeline L, Iswanto B dan Lindu M 2015. Studi Kinerja Elektrokoagulasi Menggunakan Reaktor Kontinu dan Batch terhadap Air Limbah Domestik Perkantoran Gedung Syarif Thayeb (M) Universitas Trisakti. Indonesian Journal of Urban and Environmental Technology $7(2): 67-74$

DOI: http://dx.doi.org/10.25105/urbanenvirotech.v7i2.716

Castro-Barros, C. M., Revised by Volcke, E. I. P., 2013, Guidline for granular sludge reactor design, SANITAS Sustainable and Integrated Urban Water System Management

Chiavola, A., Sirini, P., Cecili, S., 2010, Technical and Experimental evaluation of an innovative decentralized technology for the municipal wastewater treatment in the city of Rome, Water Science \& Technology 62(4): 956-962

DOI: https://doi.org/10.2166/wst.2010.332

De Kreuk, M dan van Loosdrecht 2006, Formation of Aerobic Granules with Domestic Sewage. Journal of Environmental Engineering, 132 (6) : 694-697

DOI: 10.1061/(ASCE)0733-9372(2006)132:6(694)

Dutta A dan Sarkar S 2015. Sequencing Batch Reactor for Wastewater Treatment: Recent Advances. Curr Pollution Rep 2015 (1):177-190

DOI: $10.1007 / \mathrm{s} 40726-015-0016-y$

Iswanto, Bambang 2010. Teknologi Elektrokoagulasi Hasil Penelitian untuk Pengolahan Limbah Domestik. Indonesian Journal of Urban and Environmental Technology 5(4) : 113-136 DOI: http://dx.doi.org/10.25105/urbanenvirotech.v5i4.681 
Ivanov, V., \& Tay, S. T. L., 2006, Seeds for Aerobic Microbial Granulation, Chapter in Waste Management Series 6: Biogranulation Technologies for Wastewater Treatment, Elsevier Page 213-244.

Kholif, M A dan Ratnawati R 2017. Pengaruh Beban Hidrolik Media dalam Menurunkan Senyawa Ammonia pada Limbah Cair Rumah Potong Ayam (RPA). Jurnal Waktu, 15(1): $1-9$ ISSN : $1412-1867$

Li, Z.H., Kuba, T., Kusuda, T., 2006, Aerobic Granular Sludge: a promising technology for decentralized wastewater treatment. Water, Science and Technology. 53(9): 79- 85 DOI: https://doi.org/10.2166/wst.2006.278

Loosdrecht, M. C. M., 2011, Graular Sludge from Idea to Pilot Plant, Paper on Symposium at Epe 9 May 2012

Minh, N. D., 2006, Treatment of High-Strength Organic Wastewater Using an Aerobic Granular System With Baffled Membrane Bioreactor, Thesis at Asian Institut of Technology

Ni, B. J 2013, Formation, characterization, and Mathematical Modeling of The Aerobic Granular Sludge, Springer Theses, 131

DOI: http://dx.doi.org/10.1007/978-3-642-31281-6

Singgih M L dan Kariana M. 2008. Peningkatan Produktifitas dan Kinerja Lingkungan dengan Pendekatan Green Productivity pada Rumah Pemotongan Ayam XX. Jurnal Purifikasi. 9(2) : 79- 90

DOI: $10.12962 / \mathrm{j} 25983806 . v 9 . i 2.149$

S. Vigneswaran, M. Sundaravadivel, D. S. Chaudhary 2011 Sequencing Batch Reactors: Principles, Design/Operation and Case Studies, Water and Wastewater Treatment Technology

V.P. Singh dan Sachan Neelam, 2011. Meat Species Specifications to Ensure the Quality of Meat-A Review. International Journal of Meat Science 1(1): 15-26.

DOI: 10.3923/ijmeat.2011.15.26

Winkler, M.K.H., 2012, Thesis on segregation of biomass in aerobic granular sludge, Disertation Doctoal on Technische Universiteit Delft

Morgenroth, E., T. Sherden, M. C. M. Van Loosdrecht, J. J. Heijnen, P. A. Wilderer, 1997, Aerobic granular sludge in a sequencing batch reactor. Water Research 31(12): 3191-3194

DOI: https://doi.org/10.1016/S0043-1354(97)00216-9 